\title{
Diachronic Corpora as a Tool for Tracing Etymological Information of Indonesian- Malay Lexicon
}

\section{${ }^{\star}$ Kamal Yusuf ${ }^{1}$, Dewi Puspita²}

UIN Sunan Ampel Surabaya, Indonesia ${ }^{1}$; Universitas Indonesia, Indonesia ${ }^{2}$

E-mail: kamalinev@gmail.com¹, dewi_puspita18@yahoo.com²

Corresponding Author

DOI: https://doi.org/10.18326/rgt.v13i1.153-182

\section{Submission Track:}

Received: 07-02-2020

Final Revision: 23-05-2020

Available online: $01-06-2020$

\begin{abstract}
Indonesian lexicon comprises numerous loanwords which some of them already exist since the $7^{\text {th }}$ century. The large number of loanwords is the reason why many dictionaries of Indonesian etymology available today contain merely the origin of the words. Meanwhile, there are several aspects in a word etymology that can be studied and presented in a
\end{abstract}


dictionary, such as the change in a word form and in its meaning. This article seeks to demonstrate the use of corpora in identifying the etymological information of Malay words from diachronic corpora and to figure out the semantic change of the Malay words undergo from time to time until they turn out to be Indonesian lexicon. More specifically, two selected Malay words were examined: bersiram and peraduan. By exploring data resources from the corpus of Malay Concordance Project and Leipzig Corpora, this study attempts to collect etymological information of Indonesian lexicon originated from Malay by employing a corpus based research. The findings show that the examined words have changed in meaning through generalization and metaphor. However, unlike the word bersiram, the change that the word peraduan happened only occurs in semantic level. This information, ultimately, can be used as informative data for a more comprehensive Indonesian etymology dictionary. Drawing on corpus analysis, this paper addresses the importance use of diachronic corpora in tracing words origin.

Keywords: diachronic corpora, etymology, corpus analysis, semantic change, Malay-Indonesian

\section{INTRODUCTION}

For most language users, etymological information is perceived just evidence of which a word originated from, especially when a language absorbs many loanwords; Indonesian take as an example (Russel et al., 2007; Tadmor, 2009). Kridalaksana (2001) pointed out that the content of Indonesian etymology dictionaries which have been compiled and available today is merely an inventory of words origin which needs to be continued with research and interpretation from various aspects. This is in line with the opinion of Durkin (2009) and 
Liberman (2009) who stated that the study of etymology is related to the history of a word, the history of meaning, formal history, or the history of its spread from one language to another, or from one group to another. In accordance with that, it is important to point out that at least there are six etymological information that can be applied to trace a word: (1) the year of usage, (2) the initial form (morphology) and the initial sound (phonology), (3) the language of the donor (for loan word), (4) the person who coined the word for the first time, (5) the initial meaning, and (6) the change of meaning. Therefore, an etymological dictionary should not only contain information of the word's origin but also be given more clear-cut description of a word.

Other things from Indonesian etymology dictionaries that are available until today is the scarcity of etymology information of words originated from Malay. Malay is the root of Indonesian (Teeuw, 1967; Andaya, 2001; Hoogervorst, 2015). In the early centuries, the language spoken in some part of the Indonesian archipelago and the Malay Peninsula might be the same. Over time, there are many things and events, socially and politically that affects the regions and causes the language to change and to be different. Information of changes that occur in Malay words--that now become the vocabulary of Indonesia, phonologically, morphologically, semantically, or syntactically-- are parts of the etymology information (Mohamed \& Yusoff, 2014).

A number of studies have previously been done concerning the etymology and semantic change of words in various languages, to mention some are Wijaya \& Yeniterzi, 2011; Yurrivna, 2014; Jatowt \& 
Duh, 2014; Hasan, 2015; and Altakhaineh, 2018. However, to date, there is not ample works that pay their attention to scrutinize how the etymological information can be approached using corpora, especially in the relation of Malay and Indonesian language.

Wijaya \& Yeniterzi (2011) identified semantic change of words over centuries using computational linguistics method. They used Topics-Over-Time (TOT) and k-means clustering on Google Books Ngram dataset. Through their methods, they show how clustering words that co-occur with an entity of interest in 5-grams can shed some lights to the nature of change that occurs to the entity and identify the period for which the change occurs. Yurrivna (2014) only classified changes in meaning that occur in English medical terms. Classification of changes in meaning in question is specialization, generalization, pejoration or amelioration, also metaphor and metonymy.

Jatowt \& Duh (2014) explored digitized historical texts, which were also carried out in our study. The difference is, Jatowt $\&$ Duh uses the NLP (Natural Language Processing) method while we used the corpus-based method. Another study was conducted by Hasan (2015) which dealt with semantic change of borrowing words, especially Arabic words in Bengali. This kind of research in Indonesian is plenty. In fact, most of etymological research in Indonesian is about borrowing words.

Altakhaineh (2018) examined the semantic change of positive vs. negative adjectives in Modern English. He compared the meaning of those adjectives in dictionary than look up their frequency of use in the corpus. He wanted to see wether the adjective had been negative or 
positive from the beginning or whether the adjective turns negative or positive because there are things that cause it. The research object of the those researchs are English vocabulary.

Until now there has been no theory that specifically addresses the search for etymological information through diachronic corpora. Existing theories still separate theory of etymology and theories about corpus linguistics. Of the two theories, the theory referred to in this study is the theory of Collins (2003) and the theory of collocation via concordance from McEnery \& Hardie (2012). The search for etymological information through diachronic corpus is nothing new for Indo-European languages, especially English. However, for the Indonesian language, especially those from Malay, no one has ever discussed this matter. Our current research deals with original words, i.e. the Indonesian words that are rooted from Malay, not from any foreign loan words. Most importantly, none of the previous studies used a corpus-based method, in particular comparing data through diachronic corpora.

This paper offers a tool that can be used to trace etymological information, especially to trace changes in their meaning. The tool that can provide a large collection of text from past centuries to be examined is diachronic corpora (de Melo, 2014). According to Allan \& Robinson (2012), the use of corpus is the state of the art in the study of historical semantics, which is part of etymology study. Malay is fortunate to have Malay Concordance Project (MCP) developed by Australian National University (Proudfoot, 1991; Gallop, 2013). It consists of old classical 
Malay manuscripts from $14^{\text {th }}$ to $20^{\text {th }}$ centuries that can be used to examine the usage of a Malay word during that time (Johary \& Rahim, 2014). This present study, therefore, seeks to explore any etymological information of Malay words that become part of Indonesian lexicon which are still used until today by employing the MCP compared with a more recent potential corpus from the $21^{\text {st }}$ century.

There are thousands of Malay-Indonesian original vocabularies. It would take a very long time to be able to analyze the entire original vocabulary. For this reason, as a preliminary study, the current research was conducted using data samples. Two samples were chosen to be presented in this paper; they are bersiram and peraduan. The sample selection process is explained in the research method section.

Thus, the aims of the current study have three folds: (1) to identify the etymological information of Malay words bersiram and peraduan from diachronic corpora, (2) to investigate what kind of changes those Malay words undergo from time to time until they turn out to be Indonesian lexicon, and at the end (3) to demonstrate the use of diachronic corpora as a tool in examining etymological Malay-Indonesia lexicon.

\section{RESEARCH METHOD}

This research is a corpus-based research. To prove that etymological information can be collected from diachronic corpora, this study employed two corpora that were set in chronological order. We started with the methodological issue by selecting the proper corpora 
collection available online. We found two major salient collections regarding Malay and Indonesian corpus. The first corpus is MCP, which comprises 5.8 million words (including 140,000 verses) from more than 165 sources of pre-modern Malay written text. The oldest script is from the year 1302 and the most up-to-date is from 1950 (Gallop, 2013; Bakar, 2020). However, the dates of some old scripts are somewhat hypothetical. The second corpus as a source for identifying the etymological information of this study is taken from the Indonesian corpus from Leipzig Corpora. This corpus is based on online material from 2012 to 2014 that consists of 74,329,815 sentences, 7,964,109 types, and 1,206,281,985 tokens (Richter et al., 2006; Biemann et al., 2007). The two corpora are available online and they demonstrate the context uses of Malay lexicon from the $14^{\text {th }}$ to $21^{\text {st }}$ century.

The search results of the words investigated from the two corpora then were analyzed qualitatively. The changes that each word undergoes were examined from the concordance lines and the word's collocations. Collocation analysis usually involved statistical measurement. Yet, McEnery \& Hardie (2012) proposed a non-statistical method called collocation-via-concordance technique. In this technique, researchers must use their intuitive to check the concordance lines that yield up notable examples and patterns, and then examine each line individually. Therefore, with certain considerations, we undertook this technique for the recent study.

Regarding the data, we selected two samples from a number of Malay-Indonesian words to be further investigated as a model study in 
this paper, i.e. bersiram and peraduan. Those words are taken from the list of honored words in Kamus Besar Bahasa Indonesia (KBBI). Honored words mean words that are used in formal situation and only for selected and respected people. There are 26 words in that list (Table 1). However, not all of them are originated from the Malay. Some of the words listed are originated from Sanskrit and Old Javanese. Most importantly, not all of them experience changes in their meaning. From that not so many Malay words that undergo changes in meaning, we found the word bersiram and peraduan.

Table 1. List of words labeled hor in KBBI

\begin{tabular}{llll}
\hline Nr. & Word & Nr. & Word \\
\hline 1 & abangda & 14 & bersiram \\
2 & adimas & 15 & dalem \\
3 & adinda & 16 & eyang \\
4 & ananda & 17 & jenazah \\
5 & apa & 18 & mangkat \\
6 & asma & 19 & meninggal \\
7 & ayahanda & 20 & nenenda \\
8 & ayunda & 21 & pakanira \\
9 & baginda & 22 & pamanda \\
10 & beliau & 23 & peraduan \\
11 & beradu & 24 & pesiraman \\
12 & bersantap & 25 & suaminda \\
13 & bersemayam & 26 & surai \\
\hline
\end{tabular}

\section{RESULTS \& DISCUSSION}

Given the above description, we primarily present an analysis model of utilizing diachronic corpora to discover the etymological 
information of Malay-Indonesia lexicon. We selected bersiram and peraduan and traced their use in the sentences deposited from the two corpora as presented below.

\section{Diachronic Use of "'bersiram"'}

The word bersiram is a high classical Malay word. The word has been recorded in the dictionaries of Malay (Kamus Dewan, 2015; Pusat Rujukan Persuratan Melayu, 2020) and Indonesian (Kamus Besar Bahasa Indonesia, 2020) with the meaning of 'to take a bath'. The word can only be used for the royal family. In MCP, this word appeared 157 times in 24 old manuscripts dated from the year 1370s to 1930s (as can be seen in Table 1 and 2). Bersiram occurred 32 times in Salasilah Melayu dan Bugis (1865) and only one time in the manuscripts Syair Ken Tambuhan ( 1750), Hikayat Raja Bikrama Sakti (1800), Syair Nyamuk dan Lalat (<1873), Hikayat Purasara (>1890), Syair almarhum Sultan Abubakar (1896), Syair Raja Johor (1899), and Cerita Jenaka (<1908).

Table 2. Distribution of results of bersiram in MCP

\begin{tabular}{ccc}
\hline \multicolumn{3}{c}{ bersiram (1300-2000) } \\
\hline $1370 \mathrm{~s}$ & 4 & Bayan 4 \\
$1700 \mathrm{~s}$ & 2 & Tuah 2 \\
$1750 \mathrm{~s}$ & 1 & KT 1 \\
$1770 \mathrm{~s}$ & 5 & ARM 5 \\
$1780 \mathrm{~s}$ & 5 & Misa 5 \\
$1800 \mathrm{~s}$ & 1 & Bik 1 \\
$1810 \mathrm{~s}$ & 17 & PNB 17 \\
$1820 \mathrm{~s}$ & 8 & Zub 8 \\
\hline
\end{tabular}




\begin{tabular}{|c|c|c|}
\hline $1870 \mathrm{~s}$ & 5 & $\begin{array}{c}\text { Nymk 1, NAsik 2, KS } \\
2\end{array}$ \\
\hline $1880 \mathrm{~s}$ & 28 & $\begin{array}{c}\text { 1880s } 28 \text { Pah } 2, \mathrm{Mpt} \\
26\end{array}$ \\
\hline $1890 \mathrm{~s}$ & 5 & $\begin{array}{c}\text { SSiti 2, Puras 1, SAB } \\
\text { 1, RJoh 1 }\end{array}$ \\
\hline $1900 \mathrm{~s}$ & 1 & CJen 1 \\
\hline $1910 \mathrm{~s}$ & 6 & J\&P 6 \\
\hline $1930 \mathrm{~s}$ & 13 & TZA 13 \\
\hline
\end{tabular}

All those 157 tokens of bersiram demonstrate the same meaning in the contexts with those recorded in dictionaries. Below are some examples of bersiram in some contexts:

\section{0s}

(1) sudah Élah kembali itu, maka bagindapun pergilah bersiram ke kolam itu. Setelah sudah baginda bersiram itu,

'Elah came back, so the king takes a bath in the pool. After taking a bath,'

\section{0s}

(2) Setelah selesailah daripada bercukur dan bersiram putera Baginda itu, maka datanglah bidan menjunjung duli ...

'After the prince has shaved and took a bath, the midwife took a bow' 
1810s

(3) ...anéka jenis daripada bungaan. Setelah sudah mandi bersiram maka naiklah segala puteri-puteri itu mengentas bunga2an ada yang ...

'various of flowers. After taking a bath then the girls get up to remove all those flowers...'

1890s

(4) ... sama elok parasnya. | Setelah genap tujuh hari, Bersiramlah baginda laki isteri, Dikerjakan oleh perdana menteri,

'Look as pretty. After seven days, the king and his queen took a bath, Done by the prime minister'

\section{0s}

(5) Pada suatu hari Sultan Mahmud hendak berangkat bersiram, duduk di atas julangan, ditikam oleh Megat Sri Rama dengan ...

'Once upon a time Sultan Mahmud is going to take a bath, while sitting, stabbed by Megat Sri Rama using...’

\section{0s}

(6) ... bestari, manakala siang keluar matahari, selesai bersiram mahkota negeri. | Berangkat keluar ia bertakhta, tersenyum ...

'...smart, when the sun rises in the afternoon, the crowned head took a bath. He comes out to enthrone, smiles...'

The above concordance lines show that the word bersiram collocated with the word baginda (king), puteri-puteri (princesses), perdana menteri (prime minister), Sultan Mahmud (King Mahmud), and 
mahkota negeri (crowned head). The other concordance lines which are not presented here also show the same collocates. Those collocates indicate that the word bersiram is only used for the royal family. The line from the 1890s (as in the sentence 4) even shows that the bath was not just a usual bath, it was a kind of ceremony.

(4) ... Setelah genap tujuh hari, Bersiramlah baginda laki istri, Dikerjakan oleh perdana menteri, ...

'... After seven days, The king and his queen took $\boldsymbol{a}$ bath, Done by the prime minister, ...'

Table 3. Frequency of occurrences bersiram in the MCP manuscripts

\begin{tabular}{lcc} 
M\&B Salasilah Melayu dan Bugis & 1865 & 32 \\
Mpt Hikayat Merpati Mas dan & $>1883(M S 1887$ & 26 \\
Merpati Perak & & \\
PNB Hikayat Perintah Negeri & $1811(M S 1811)$ & 17 \\
Dmsy.S Syair Raja Damsyik & 1864 & 16 \\
TZA Syair Tawarikh Zainal Abidin & 1936 & 13 \\
yang Ketiga & & \\
Zub Syair Siti Zubaidah Perang & $\sim 1800(M S 1840)$ & 8 \\
Cina? & & \\
TN Tuhfat alNafis & $1866(M S 1890)$ & 6 \\
J\&P Hikayat Johor serta Pahang & 1917 & 6 \\
ARM Adat Raja Melayu & $1779, \sim 1850(M S S$ & 5 \\
& $1817,1873)$ & \\
Misa Misa Melayu & $\sim 1780(M S 1836)$ & 5 \\
Bayan Hikayat Bayan Budiman & $1371(M S 1852)$ & 4 \\
Tuah Hikayat Hang Tuah & $\sim 1700(M S 1849)$ & 2 \\
NurP Syair Sultan Nur Peri & $<\sim 1865$ & 2 \\
NAsik Hikayat Nakhoda Asik & $\sim 1870(M S 1890)$ & 2 \\
KS Kitab Suci PL & $1879, P B: 1935$ & 2 \\
Pah Hikayat Pahang & $1883(M S 1883,1932)$ & 2 \\
SSiti Syair Seratus Siti? & $\sim 1890$ & 2 \\
\hline
\end{tabular}




\begin{tabular}{lcc}
\hline KT Syair Ken Tambuhan & $\sim 1750(M S 1791-1872)$ & 1 \\
Bik Hikayat Raja Bikrama Sakti & $\sim 1800(M S 1830)$ & 1 \\
Nymk Syair Nyamuk dan Lalat & $<1873$ & 1 \\
Puras Hikayat Purasara & $>1890$ & 1 \\
SAB Syair almarhum Sultan & 1896 & 1 \\
Abubakar & & \\
RJoh Syair Raja Johor & 1899 & 1 \\
CJen Cerita Jenaka & $<1908$ & 1 \\
\hline
\end{tabular}

\section{The Semantic Change of "bersiram"'}

After its independence in 1945, Indonesia has become a republic. The royal system is no longer used. For that reason, the frequency of use of the word bersiram might also be decreased. However, in a more recent corpus like Indonesian corpus in Leipzig Corpora, we can still find the use of the word bersiram in many different contexts (see graphic in Figure 1). The figure is an automatic generated collocation graphic from Leipzig Corpora. As can be seen, the graphic contains words related to the word bersiram found in the corpus. The graphic depicts that in their corpus, the word bersiram collocates or related to all those words. The collocates found in the graphic are different with those found in MCP corpus. In corpus linguistics, collocation means words which occur within the neighbourhood of another word. Those words don't have to be located right next to the main word (Baker et al, 2006: 36-37). The search of the word bersiram in Leipzig Corpora are turned in 55 lines. There are some interesting findings from the lines, such as: 
a. From 55 occurrences, only 15 of them have the literal meaning of 'to take a bath' or 'to shower'. Ten lines, which come from Malaysian website, use the word bersiram as the equivalent of to take a bath or shower in the daily activity of common people, while the other five lines, which come from Indonesian website, still use the word only for a respected person.

b. Six lines contain the word bersiram in a figurative meaning. In those lines, the word bersiram is used in the form of a metaphor. Bersiram is juxtaposed with darah (blood) and cahaya (light) as in the sentence (7):

(7) Di kejauhan tampak gedung-gedung jangkung

yang bersiram cahaya lampu.(www.mayasanti.blogspot.

com, crawled on 08/05/2012)

'In the distance, tall buildings are seen bathed in light.'

c. The most interesting finding is, 34 lines of them appeared in the contexts of food and carry a figurative meaning. In those lines, bersiram mostly collocates with saus (sauce), jamur (mushroom), keju (cheese), cokelat (chocolate). One example of the word usage in the context of food is as in the sentence (8):

(8) Dari deretan menu terbaru, ada BBQ Beef Ribs \& Alice Springs

Chicken bersiram saus keju Monterey Jack-Cheddar.

(www.femina.co.id, crawled on 06/02/2014)

'From the latest menu, there are a BBQ Beef Ribs \& Alice Springs Chicken covered with Monterey Jack-Cheddar cheese sauce. 
We can see from the two diachronic corpora that there are changes in the meaning of the word bersiram. The word that originally had only one meaning and used only for certain circle, after the twentieth century its meaning has widened to a figurative meaning, and move from specific to a more general meaning.

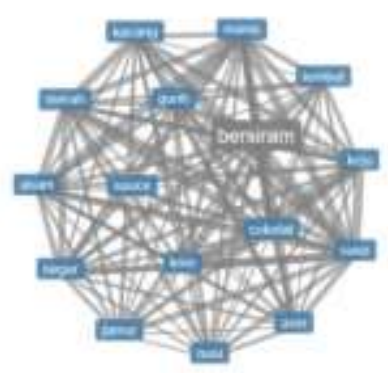

Figure 1. Collocations of bersiram as shown in Corpora Collection Leipzig University

As can be seen from Figure 1, the graph is an auto-generated graph based on the frequency of co-occurences. The words darah and cahaya do not appear on the graph because the frequency of their appearance is not as high as other words.

Furthermore, it is not only the semantic aspect of the word bersiram that change over time. Another linguistic aspect that also changes is the syntactic aspect, especially at class of word. Bersiram is an intransitive verb by nature. In Indonesian grammar, prefix ber-forms intransitive verb. As can be seen in the sentence (9):

(9) ... maka bagindapun pergilah bersiram ke kolam itu. 
'... then the King went to the pool to take a bath.'

The phrase ke kolam itu in above sentence (1) is not an object, but it is an adverb of place. An object is not needed after the word bersiram in that sentence.

However, in its figurative meaning, the verb bersiram has become transitive. Below is a concordance line of the verb bersiram in figurative meaning followed by its objects (in upright letters).

(10) Tempat orang berniaga dikepalai seorang batin bijaksana yang mengharamkan negeri bersiram darah.

'A place for trading is lead by a wise man who forbid the land from bloodshed.

(11)Di kejauhan tampak gedung-gedung jangkung yang bersiram cahaya lampu.

'In the distance, tall buildings are seen bathed in light.'

(12) Sejumput mi bersiram saus dengan potongan udang gemuk di atasnya.

'a pinch of noodles doused in sauce with a oiece of fat shrimp on its top.

(13) Versi Michel's disebut Marble Mud Cake, bersiram ganache cokelat putih dan cokelat pekat.

'Michel's version is called Marble Mud Cake, covered by ganache chocalate

(14) Dan, sebagai penutup pesanlah Roti Cane Gula atau Roti Cane Susu, bersiram susu kental manis. 
'And, as a desserts please order Roti Cane Gula or Roti Cane Susu, watered with condensed milk'

Objects in the above sentences are mandatory because without objects the sentences would be incomplete and meaningless.

\section{Diachronic Use of 'peraduan"'}

Another example that we would like to present for tracing the semantic change and the etymological information utilizing MCP is the word peraduan. This word is a classical-high Malay as well, that is used strictly for the royal family. It has the meaning of 'bed' or 'bedroom'. Compared to bersiram, the frequency of peradaun's appearance in MCP was found higher. It appeared 357 times in 31 old manuscripts dated from the 1370s to 1950s. The word can be found in the manuscript Syair Siti Zubaidah Perang Cina (32 times) and mostly occurred one time in sixteen manuscripts (see Table 3). The sentences below are some examples from the concordance lines from the manuscripts showing the uses of peraduan in the contexts whereby all with the meaning of 'bed' and 'bedroom'. .. ketiganya itu pun masing-masing mendapatkan biliknya peraduan, lalu beradulah sekaliannya itu.

'...all of three get their bedrooms, then they sleep.

... beri rawan, sendu rupa kelakuan, buka ranjang

peraduan. | Lalu makai Sinyor Gilang, baju lakan hitam gilang

'...be vulnerable, sentiment behavior, go to the bed. Then Sinyor Gilang wearing, a black trouser ${ }^{6}$ 
Maka Kuda Nestapa pun masuk ke dalam peraduan lalu menyingkap tirai kelambu itu. Maka dilihatnya Raden...

'...Then the Sorrow Horse gets into the bedroom, opens the curtain. So, he looks at Raden...

(18) Sambil memakai bau-bauan. Adinda disambut masuk peraduan. | Lalulah duduk menanggalkan jubah,

'...wearing parfumes. Adinda welcomed into his bedroom. Then he took off his robe,

... biliknya dan pada tiap-tiap bilik itu ditaruhnya geta

peraduan lengkap dengan kasur, tilam dan tirai ...

'...his room and in every bedroom equipped with mattress and curtain

(20) ... bilik yang indah. | Istana besar apa gunanya, Peraduan lengkap dengan perhiasannya, Asingnya tidak ...

'beautiful bedroom, what a point of a big palace, a full furnished bedroom with decorations, ...

Table 4. Frequency of occurrences peraduan in the MCP manuscripts

\begin{tabular}{lcc}
\hline Zub Syair Siti Zubaidah Perang Cina & $? \sim 1800(M S 1840)$ & 32 \\
Panji Hikayat Panji Kuda Semirang & $? \sim 1750(M S 1832)$ & 28 \\
Mar Hikayat Maharaja Marakarma & 1844 or 1848 & 27 \\
SSiti Syair Seratus Siti & $? \sim 1890$ & 22 \\
PandL Hikayat Pandawa Lima & $\sim 1525 \quad ?$ & 15 \\
& $1371(M S 1852)$ & 14 \\
Bayan Hikayat Bayan Budiman & $\sim 1600(M S 1850)$ & 12 \\
Boma Hikayat Sang Boma & $<1600(M S 1700)$ & 10 \\
Ind Hikayat Inderaputera & $\sim 1750(M S 1825)$ & 10 \\
Bid Syair Bidasari &
\end{tabular}




\begin{tabular}{|c|c|c|}
\hline AHmz Hikayat Amir Hamzah & $<1380$ & 9 \\
\hline JPati Hikayat Putera Jaya Pati & ? 17.. (MS 1819) & 9 \\
\hline KT Syair Ken Tambuhan & $\begin{array}{c}\sim 1750(M S 1791- \\
1872)\end{array}$ & 9 \\
\hline Dmsy.H Hikayat Raja Damsyik & 1863 & 9 \\
\hline Kosta Syair Sinyor Kosta & $<1821(M S$ 1862) & 8 \\
\hline Dmsy.S Syair Raja Damsyik & 1864 & 8 \\
\hline S Saudara & 19301935 & 8 \\
\hline Anb Surat alAnbiya' & $\sim 1750($ MS 1877) & 7 \\
\hline Sikka Hikayat Kerajaan Sikka & $\begin{array}{c}19251953(M S \\
1979)\end{array}$ & 7 \\
\hline Aceh Hikayat Aceh & $\sim 1625(M S \sim 1675)$ & 6 \\
\hline Tuah Hikayat Hang Tuah & 1700 (MS 1849) & 6 \\
\hline PiagM Piagam Muara Mendras & $\sim 16601880$ & 6 \\
\hline SMrdn Hikayat Syah Mardan & $\sim 1720(M S<1871)$ & 5 \\
\hline ARM Adat Raja Melayu & $\begin{array}{c}1779, \sim 1850(M S S \\
1817,1873)\end{array}$ & 5 \\
\hline ABS Hikayat Ali Bad Syah & ? $1800(M S 1826)$ & 5 \\
\hline Bik Hikayat Raja Bikrama Sakti & 1800 (MS 1830) & 5 \\
\hline Nuri Syair Nuri dengan Simbangan & $\sim 1860$ & 5 \\
\hline Nymk Syair Nyamuk dan Lalat & $<1873$ & 5 \\
\hline Kumb Syair Kumbang Mengindera & $<1859$ & 4 \\
\hline NurP Syair Sultan Nur Peri & $<\sim 1865$ & 4 \\
\hline Puras Hikayat Purasara & 1625 (MS 1849) & 4 \\
\hline Kutai Cerita Kutai & 1625 (MS 1849) & 3 \\
\hline SM Sejarah Melayu & 1612 (MS 1808) & 3 \\
\hline Hemop Syair Hemop & 1750s (MS 1817) & 3 \\
\hline MW Hikayat Merong Mahawangsa & $\begin{array}{l}\sim 1821 \text { (edition } \\
1898 \text { ) }\end{array}$ & 3 \\
\hline $\begin{array}{l}\text { Mpt Hikayat Merpati Mas dan Merpati } \\
\text { Perak }\end{array}$ & $>1883$ (MS 1887) & 3 \\
\hline Pasai Hikayat Raja Pasai & 1390 (MS 1815) & 2 \\
\hline Rama Hikayat Seri Rama & 15.. (MS < 1633) & 2 \\
\hline Bkht Hikayat Bakhtiar & $\sim 1650($ text 1881$)$ & 2 \\
\hline $\begin{array}{l}\text { IbrA Hikayat Ibrahim ibn Adham (long } \\
\text { version) }\end{array}$ & $\sim 1650$ (MS 1775) & 2 \\
\hline KBima Syair Kerajaan Bima & 1830 (MS 1857) & 2 \\
\hline
\end{tabular}




\begin{tabular}{|c|c|c|}
\hline Awai Syair Awai & 1868 & 2 \\
\hline INata Hikayat Indera Nata & $\sim 1870(\mathrm{MS}<1874)$ & 2 \\
\hline SAB Syair almarhum Sultan Abubakar & 1896 & 2 \\
\hline CJen Cerita Jenaka & $<1908$ & 2 \\
\hline $\begin{array}{l}\text { TZA Syair Tawarikh Zainal Abidin } \\
\text { yang Ketiga }\end{array}$ & 1936 & 2 \\
\hline PK PuisiPuisi Kebangsaan & 19131942 & 2 \\
\hline BS Bustan alSalatin & $\sim 1640$ & 1 \\
\hline ABJD Asal Bangsa Jin \& DewaDewa & $\sim 1700(\mathrm{MS}<1851)$ & 1 \\
\hline Pat Hikayat Patani & 1730 (MS 1839) & 1 \\
\hline Misa Misa Melayu & $\sim 1780($ MS 1836) & 1 \\
\hline Perb Svair Tengku Perbu & 1835 & 1 \\
\hline Siak Hikayat Siak & 1855 (MS 1893) & 1 \\
\hline M\&B Salasilah Melayu dan Bugis & 1865 & 1 \\
\hline TN Tuhfat alNafis & 1866 (MS 1890) & 1 \\
\hline PPRiau Peringatan Pelayaran ke Riau & 1868 (MS ? 1917) & 1 \\
\hline NAsik Hikayat Nakhoda Asik & $\sim 1870$ (MS 1890) & 1 \\
\hline KS Kitab Suci & PL: 1879, PB: 1935 & 1 \\
\hline Pah Hikayat Pahang & $\begin{array}{l}1883 \text { (MS 1883, } \\
1932 \text { ) }\end{array}$ & 1 \\
\hline $\begin{array}{l}\text { Guna Perhimpunan Gunawan bagi } \\
\text { Laki2 dan Perempuan }\end{array}$ & 1911 & 1 \\
\hline SKel Hikayat Seri Kelantan & $\begin{array}{c}1783-1914(\mathrm{MS} \\
1914)\end{array}$ & 1 \\
\hline M Majlis & $1932-1935$ & 1 \\
\hline VN Vernacular Newspapers Editorials & $1887-1940$ & 1 \\
\hline
\end{tabular}

In a more recent corpus such as Leipzig Corpora, the frequency of occurrence of the word peraduan is also high. There are 650 occurrences from websites dated from 2012 to 2014. However, the meaning that the word carries in this corpus is rather different from those in MCP. From about 100 lines examined from the concordance lines, there are three types of usage of the word peraduan. 


\section{The Semantic Change of "peraduan"'}

The first type has the same meaning and usage as those in previous corpus, which is bed or bedroom of the royal family. The word peraduan in the first type, as shown in sentences number (21), (22), and (23), are collocated with raja (king) and kerajaan (royal).

(21) Sementara itu, sang raja telah tidur di peraduan kerajaan.

'Meanwhile, the King had slept in the royal bed.'

(22) Jika nanti sudah berada dalam peraduan raja, cincin itu harus dilepas, dan ditaruh didekat Pusaka Keraton karena dirinya sudah berada di dalam cincin itu.

'When already in the king's bedroom, the ring must be taken off and placed near the heritage of the palace because he is already in the ring.'

(23) Sebelum mencabut tombak, ia kembali keluar dari peraduan raja yang kesakitan itu.

'Before pulling the spear, he came back out of the afflicted king's bedroom.'

In the second type of usage, the word peraduan, as found in the Leipzig Corpora, carries the same meaning but it is then used by common people. (24) Membaca buku, majalah, atau sekadar mendengarkan musik, sebelum Anda beranjak ke peraduan untuk tidur.

'Read book, magazine, or simply listen to the music before you go to bed.' 
(25) Pagi itu hujan deras menguyur kota Surabaya dan sekitarnya, membuat badan malas untuk bangkit dari peraduan.

'That morning, heavy rain was pouring in Surabaya and its surrounding area, made me lazy to get out of bed. ‘

(26) Orang-orang yang dekat di hati saya, satu persatu mulai beranjak ke peraduan.

'The people I love, one by one began to move to go to bed.'

The common word for 'bed' in Indonesian is tempat tidur or ranjang. However, in sentence (24), (25) and (26) which contexts are not related to the royal family, the word peraduan is used instead of tempat tidur or ranjang. This usage shows that the meaning of peraduan has been generalized. Since there is no longer king or royal family in Indonesia, the word has become functional for everyone.

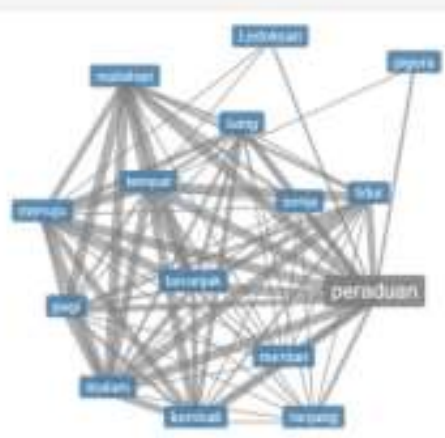

Figure 2. Collocates of peraduan in Corpora Collection Leipzig University Ine thira type is the occurrence or the wora in ilgurative meaning. In this type of usage, the word peraduan mainly collocates with 
matahari (as shown in Figure 2), such as in the sentence (27), (28) and (29); and sang surya which also means 'sun' in (30). In those sentences, the sun is depicted as if it goes to bed to rest so the day turns into night, or gets out of the bed and starts to shine.

(27) Matahari beranjak ke peraduan dan malam mulai menggeliat ke atas bumi.

'The sun goes down to its resting place and the night begins to climb the earth.'

(28) Ketika matahari telah kembali ke peraduan, malam pun tiba.

'When the sun has gone to bed, the night has come.'

(29) Matahari sudah beranjak ke peraduan, tetapi langit biru masih tersisa.

'The sun has gone to bed, but there is still some blue sky.'

(30) Salah satunya adalah untuk melihat secara langsung, Sang Surya keluar dari peraduan di ufuk timur.

'One of the reasons is to see directly the sun out of its bed in the eastern horizon.'

In Indonesian, there is a metaphor that equates the sun as the king of the day and the moon as the night goddess (_matahari=raja siang; bulan=dewi malam_). Without the sun there will be no daylight. In some cultures, there are also tribes who regard the sun as a god or as the giver of life just like a king. Because of this metaphor and belief, some of the vocabulary reserved only for kings is also applied to the sun.

Finally, those different types of usage of peraduan found in Leipzig Corpora show that the word has changed in meaning through 
generalization and metaphor. However, unlike the word bersiram, the change that the word peraduan experienced only occurs in semantic level. The other linguistic aspects of the word are not affected.

\section{CONCLUSION}

Using corpora, this paper identified the etymological information particularly of the exemplary words bersiram and peraduan to determine to what extent these words diachronically changed through time. Drawing on data obtained from the analysis, the findings showed information as follows.

\begin{tabular}{ll}
\hline Entry & : bersiram \\
\hline Initial meaning & $\begin{array}{l}\text { : 'to take a bath (intransitive), used for the royal } \\
\text { family' }\end{array}$ \\
$\begin{array}{l}\text { Additional } \\
\text { meaning }\end{array}$ & $\begin{array}{l}\text { 1. To bathe (transitive, figurative meaning), } \\
\text { (in } 21^{\text {th }} \text { century) }\end{array}$ \\
\hline
\end{tabular}

\begin{tabular}{ll}
\hline Entry & : peraduan \\
\hline Initial meaning & $:$ 'bed or bedroom, used for the royal family' \\
Additional & 1. Bed or bedroom (general), \\
meaning & 2. Resting place (figurative meaning). \\
(in 21 & \\
\hline
\end{tabular}

The presentation of the etymological information in the dictionary can also be made in the narrative form, so the reader could get a clearer picture of the semantic change (Bochkarev et al., 2020).

This paper has demonstrated that diachronic corpora can be a useful tool in the investigation of etymological information, especially 
to find changes in meaning. The corpora that are set chronologically can also tell us the approximate time of change. Although the precise year of change remains unknown, it is able to at least reveal in which era the change happen. The activity of collecting etymological information from diachronic corpora, however, can only be done to the lexicon in written texts. Furthermore, information about the usage of the words in spoken forms, whether or not they are used in the same register with the same meaning, is undisclosed. We found that, it does not lessen the effectiveness of diachronic corpora as a tool in collecting etymological information. Finally, this paper could strategically contribute to the model of development for a more comprehensive Indonesian etymology dictionary.

\section{REFERENCES}

Allan, K. \& Robinson, J.A. (eds.). (2012). Current Methods in Historical Semantics. Berlin: Walter de Gruyter.

Altakhaineh, A.R.M. (2018). The Semantic Change of Positive vs. Negative Adjectives in Modern English. Lingua Posnaniensis. 60(2), 25-37. DOI: https://doi.org.10.2478/linpo-2018-00010. Andaya, L.Y. (2001). The Search for the 'Origin' of Melayu. Journal of Southeast Asian Studies. 32(3), 315-330. DOI: https://doi.org/10.1017/S0022463401000169.

Bakar, N.S.A.A. (2020). The Development of an Integrated Corpus for Malay Language. In: Alfred R., Lim Y., Haviluddin H., On C. 
(eds) Computational Science and Technology. Lecture Notes in Electrical Engineering, vol 603. Springer, Singapore. DOI: https://doi.org/10.1007/978-981-15-0058-9_41.

Baker, Paul, et al. (2006). A Glossary of Corpus Linguistics. Edinburgh: Edinburgh University Press.

Bieman, Chris, et al. (2007). The Leipzig Corpora Collection: Monolingual Corpora of Standard Size. Accessed from https://www.birmingham.ac.uk/documents/collegeartslaw/corpus/conferencearchives/2007/190paper.pdf\&ved=2ahUKEwi6i_j4ubTnAhVSb 30KHdBFADIQFjAAegQUBRAB\&usg=AOvVaw1Fr6CtQ1Ch DmmSbkH0fzZ

Bochkarev, V., et al. (2020). A Method of Semantic Change Detection Using Diachronic Corpora Data. In: van der Aalst W., et al. (eds.). Analysis of Images, Social Networks and Text. AIST 2019. Communications in Computer and Information Science, vol 1086, 94-106. Springer, Cham. DOI: https://doi.org/10.1007/978-3-030-39575-9_10.

de Melo, Gerard. (2014). Etymological Wordnet: Tracing the History of Words. In: Proceeding of the Ninth International Conference on Language Resources and Evaluation. European Language Resources Association: Reykjavil, 1148-1154.

Collins, J.T. (1998/2018). Malay, World Language: A Short History. Kuala Lumpur: Dewan Bahasa dan Pustaka. 
Collins, J.T. (2003). Mukadimah Ilmu Etimologi. Kuala Lumpur: Dewan Bahasa dan Pustaka

Comrie, Bernard (ed.). (2009). The World's Major Languages ( $3^{\text {rd }}$ Edition). London: Routledge.

Durkin, Philip. (2009). The Oxford Guide to Etymology. New York: Oxford University Press

Gallop, Annabel Teh. (2013). The Language of Malay Manuscript Art: A Tribute to Ian Proudfoot and the Malay Concordance Project. International Journal of the Malay World and Civilisation. 1(3), 11-27.

Hasan, Mahade. (2015). Semantic Change of Words Entered into another Language trough the Process of Language Borrowing: A Case of Arabic Words in Bengali. People International Journal of Social Sciences, Special Issue 1 (1), 1375-1390.

Hoogervorst, Tom G. (2015). Tracing the Linguistic Crossroads between Malay and Tamil. Wacana. 16(2), 249-283. DOI: https://doi.org/10.17510/wacana.v16i2.378.

Jatowt, A \& Duh, K. (2014). A Framework for Analyzing Semantic Change of Words across Time. In IEEE/ACM Joint Conference on Digital Libraries, London, 229-238. DOI: https://doi.org/10.1109/JCDL.2014.6970173.

Joharry, Siti Aeisha \& Rahim, Hajar Abdul. (2014). Corpus Research in Malaysia: a Bibliographic Analysis. Kajian Malaysia. 32(1), 1743. 
Kamus Besar Bahasa Indonesia (KBBI). (2020). Accessed from https://kbbi.kemdikbud.go.id/

Kamus Dewan. (2015). Kuala Lumpur: Dewan Bahasa dan Pustaka.

Kridalaksana, H. (2001). Arah Pengembangan Kajian Etimologi Indonesia. Kata. April, 2001.

Leipzig Corpora. (2019). Retrieved from http://corpora.unileipzig.de/en?corpusId=ind_mixed_2013

Liberman, A. (2009). Word Origins and How We Know Them: Etymology for Everyone. New York: Oxford University Press.

Malay Concordance Project. (2020). Accessed from http://mcp.anu.edu.au/

McEnery, T. \& Hardie, A. (2012). Corpus Linguistics: Method, Theory and Practice. Cambridge: Cambridge University Press.

Melebek, Abdul Rashid \& Moain, Amat Juhari. (2006). Sejarah Bahasa Melayu. Kuala Lumpur: Utusan Publications.

Moeljadi, David, et al. (2019). Considerations for Providing Etymological Information in the KBBI Indonesian Dictionary. In Proceeding of the $13^{\text {th }}$ International Conference of the Asian Association for Lexicography. Istanbul, 223-240.

Mohamed, Noriah \& Yusof, Radiah. (2014). Pendekatan Kontranstif dan Komparatif Bahasa-Bahasa di Malaysia. Penang: Universiti Sains Malaysia Press.

Omar, Asmah Haji. (2005). The Encyclopedia of Malaysia: Languages and Literature. Singapore: Editions Didier Millet Pte Ltd. 
Proudfoot, I. (1991). Concordances and Classical Malay. Bijdragen tot de Taal-, Land- en Volkenkunde 147(1), 74-95. DOI: https://doi.org/10.1163/22134379-90003200.

Pusat Rujukan Persuratan Melayu. (2020). Accessed from https://prpm.dbp.gov.my/

Richter, Matthias, et al. (2006). Exploiting the Leipzig Corpora Collection. Accessed from https://.researchgate.net/publication/228517118_C_Exploiting_th e_leipzig_corpora_collection

Ricklefs, M.C. (2008). A History of Modern Indonesia since C.1200 (revised edition). London: Macmillan.

Russel, Jones, et al. (eds). (2007). Loanwords in Indonesian and Malay. Leiden: KITLV.

Sneddon, J.N. (2003). The Indonesian Language: Its History and Role in Modern Society. Sydney: UNSW Press.

Tadmor, Uri. (2009). Loanwords in Indonesian. In: Haspelmath, Martin and Tadmor, Uri (eds.). Loanwords in the Wolrld's Languages: A Comparative Handbook. Berlin: Walter de Gruyter.

Teeuw, A. (1967). The History of the Malay Language. In: Modern Indonesian Literature. KITLV. Springer: Dordrecht. DOI: https://doi.org/10.1007/978-94-015-0768-4_2.

Wijaya, Derry Tanti \& Yeniterzi, Reyyan. (2011). Understanding Semantic Change of Words Over Centuries. In the Proceeding of the 2011 International Workshop on DETecting and Exploiting 
Cultural Diversity on the Social Web, 35-40. DOI: https://doi.org/10.1145/2064448.2064475.

Yurrivna, Shumylo Myroslava. (2014). Etymological and Semantic Changes of the English Medical Terms. Science and Education a New Dimension Philology, 2(6), Issue 29, 29-31. 